\title{
Re: 'Use of androgen deprivation therapy in prostate cancer: indications and prevalence' by Connolly et al.
}

\author{
Bo-Eric Persson
}

Asian Journal of Andrology (2012) 14, 795; doi:10.1038/aja.2012.53; published online 20 August 2012

Dear Editor,

With regard to the article 'Use of androgen deprivation therapy in prostate cancer: indications and prevalence' ${ }^{1}$ which was published in Asian J Androl 2012; 14: 177-86, we would like to highlight a number of factual inaccuracies and areas that warrant further discussion.

- Table 2 specifies that gonadotropin-releasing hormone $(\mathrm{GnRH})$ antagonists should be used as second-line androgen deprivation therapy after GnRH agonists. GnRH antagonists have been evaluated as alternative agents to agonists in the first-line treatment of advanced prostate cancer and although the body of evidence for agonists is greater, the licence for degarelix does not restrict it to second-line use after these agents have failed. Furthermore, the degarelix pivotal phase III trial ${ }^{2}$ and its long-term extension ${ }^{3}$ demonstrated a number of clinical benefits for degarelix vs. the GnRH agonist, leuprolide. These include a significant improvement in prostate-specific antigen progression-free survival (which is indicative of time to castration-resistance in these patients $)^{4}$ and a significant reduction in serum alkaline phosphatase in those with metastatic disease (indicative of control of skeletal metastases). ${ }^{5}$ Unlike GnRH agonists, degarelix was not associated with an increased risk of cardiovascular events (based on an analysis of the event rate before and after initiation of degarelix in nine prospective trials; $n=1704) .{ }^{6}$ As Connolly and his colleagues point out in the conclusion of their paper, the increased risk of cardiovascular disease needs to be taken into account when evaluating the riskbenefit ratio of androgen deprivation therapy.

- Like GnRH agonists, degarelix is licensed to treat advanced prostate cancer rather than the metastatic prostate cancer as specified in Tables 1 and 2. The clinical trials on which the licence was approved include patients of all stages. According to the 2011 National Comprehensive Cancer Network guidelines (see http:// www.nccn.org/professionals/physician_gls/f_guidelines.asp), advanced disease comprises metastatic disease, prostate-specific antigen recurrence in selected patients or symptomatic disease. Advanced disease may also include patients with locally advanced disease.

- Table 1 incorrectly specifies that 'anaphylaxis' is a side effect of degarelix. Degarelix is a third-generation GnRH antagonist and unlike abarelix, it is not associated with immediate-onset hypersensitivity reactions (see Boccon-Gibod et al., 2011). ${ }^{7}$

Many thanks for bringing these points to the attention of the authors.

\section{COMPETING FINANCIAL INTERESTS}

The author is a practicing urologist and employed by Ferring Pharmaceuticals.

1 Connolly RM, Carducci MA, Antonarakis ES. Use of androgen deprivation therapy in prostate cancer: indications and prevalence. Asian J Androl 2012; 14: 177-86.

2 Klotz L, Boccon-Gibod L, Shore ND, Andreou C, Persson BE et al. The efficacy and safety of degarelix: a 12-month, comparative, randomized, open-label, parallel-group phase III study in patients with prostate cancer. BJU Int 2008; 102: 1531-8.

3 Crawford ED, Tombal B, Miller K, Boccon-Gibod L, Schröder F et al. A phase III extension trial with a 1-arm crossover from leuprolide to degarelix: comparison of gonadotropin-releasing hormone agonist and antagonist effect on prostate cancer. J Urol 2011; 186: 889-97.

4 Tombal B, Miller K, Boccon-Gibod L, Schröder F, Shore N et al. Additional analysis of the secondary end point of biochemical recurrence rate in a phase 3 trial (CS21) comparing degarelix $80 \mathrm{mg}$ versus leuprolide in prostate cancer patients segmented by baseline characteristics. Eur Urol 2010; 57: 836-42.

5 Schröder FH, Tombal B, Miller K, Boccon-Gibod L, Shore ND et al. Changes in alkaline phosphatase levels in patients with prostate cancer receiving degarelix or leuprolide: results from a 12-month, comparative, phase III study. BJU Int 2010; 106: $182-7$

6 Smith MR, Klotz L, van der Meulen E, Colli E, Tankó LB. Gonadotropin-releasing hormone blockers and cardiovascular disease risk: analysis of prospective clinical trials of degarelix. J Urol 2011; 186: 1835-42.

7 Boccon-Gibod L, van der Meulen E, Persson BE. An update on the use of gonadotropinreleasing hormone antagonists in prostate cancer. Ther Adv Urol 2011; 3: 127-40. 